Journal of Economics, Finance and Accounting Studies (JEFAS)

ISSN: $2709-0809$

DOI: 10.32996/jefas

Journal Homepage: www.al-kindipublisher.com/index.php/jefas

\title{
The Impact of Logistics on Marketing Margin in the Philippine Agricultural Sector
}

\author{
Micaella A. Chong ${ }^{1}$, Ma. Lexa D. Cordova ${ }^{2}$, Angelica Anne M. Quintana ${ }^{3} \square$ and Peter Jeff C. Camaro, M.A ${ }^{4}$ \\ ${ }^{1234}$ Business Economics Department, College of Commerce and Business Administration University of Santo Tomas, Manila, \\ Philippines
}

$\square$ Corresponding Author: Angelica Anne M. Quintana, E-mail: lycaquintana@gmail.com

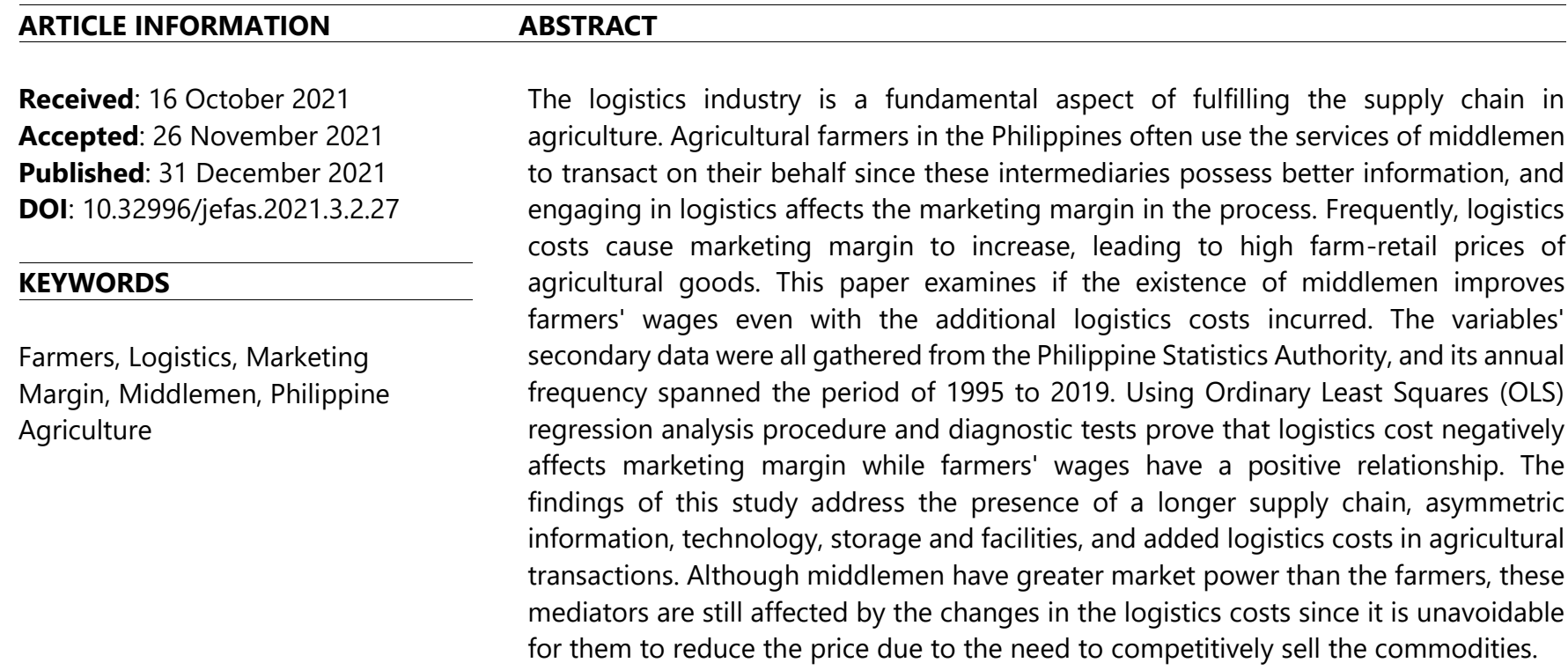

\section{Introduction}

The Philippines is one of the several emerging countries in Asia whose primary agricultural country despite the urge to industrialize it. Philippine agriculture is at a competitive disadvantage due to its inefficient logistics systems. Logistics is increasingly gaining importance for all industries, including the agricultural sector. Constraints in agriculture, such as lack of market information, urge the farmers to use Middlemen as they cannot transact on their own, thereby increasing transaction costs. Moreover, the indispensable need for transportation services to deliver these commodities influences the farmers' wages and the price spread. A significant amount of the country's population is based on rural areas wherein residing families' livelihood depends heavily on farming to sustain their needs which is frequently insufficient for a household.

The agriculture sector absorbed 9.72 million persons, contributing 22.9 percent to national employment. In nominal terms, the daily wage rate of agricultural workers in 2019 averaged PHP 331.10 (Philippine Statistics Authority, 2020). Consuming agricultural food is a necessity for people. To meet the demands in this sector, expansion and assistance to the farming industry and their development are crucial. The Philippines' economy is undergoing a structural transition, similar to that of other rapidly developing and urbanizing middle-income countries. Between 2008 and 2018, the share of agriculture in the national gross domestic product (GDP) fell from $13 \%$ to $9.3 \%$, while the share of services increased. Agriculture's shrinking share of the macroeconomy need does not have to, and does not, imply that it is stagnating or decreasing.

A flourishing agricultural sector can significantly contribute to a country's economy, social stability, and resilience during structural transformation. However, the Philippines' structural change has been slow, suggesting that its agriculture is not performing to its full potential and is not contributing fully to the national (and rural) economy. The country's agriculture is experiencing slow output,

Copyright: (C) 2021 the Author(s). This article is an open access article distributed under the terms and conditions of the Creative Commons Attribution (CC-BY) 4.0 license (https://creativecommons.org/licenses/by/4.0/). Published by Al-Kindi Centre for Research and Development, London, United Kingdom. 
productivity, trade growth, and limited structural and technological change, both in absolute terms and relative to regional peers (World Bank, 2020).

With transportation as the main component in the previous years, the logistics industry continuously emerged globally and is the lifeblood of economies (Sezer \& Abasiz, 2017). The use of logistics in Agri-Food farming is an integral part of a developing country, and within it is an integrated system that controls and organizes its various processes. Logistics functions are to transport and store agricultural products transferred to a middleman or carried out at the shipper's responsibility by a market wholesaler (Gonzaga et al., 2020). In the agri-food supply chain, the quality and quantity of the products delivered is a significant factor in their efficiency. In the food and agriculture supply chains, the logistics area focuses on transportation services that include costs that farmers and intermediaries incur in delivering the produced output to the consumers.

In practice, the flow of agricultural commodities usually starts at the farm (sometimes passed through a storage phase). It goes directly to rural (tertiary) markets that were stored or passed to secondary markets where intermediaries (middlemen) and wholesalers purchase sizable stocks and convey them to primary or main markets or storage (FAO, 2011). Agricultural commodities are commonly manufactured outside the metro cities due to the large geographic areas available in rural places, wherein it is easier to grow and foster these farm goods. Agricultural products such as fruits and vegetables have seasonal growth, universal and allyear demand, and various biological features. All of this involves high time and technological requirements on the logistics process such as transportation, storage, and processing in circulation. Given that most agricultural commodities are transported back and forth, this entails costs that affect the farmers, logistics, and end consumers. Therefore, the following issues were addressed in this paper: the impact of logistics on the farm-retail price spread, the response of farmers' wages to changes in the transaction, and the importance of farmers dealing with marketing intermediaries.

\subsection{Conceptual Framework}

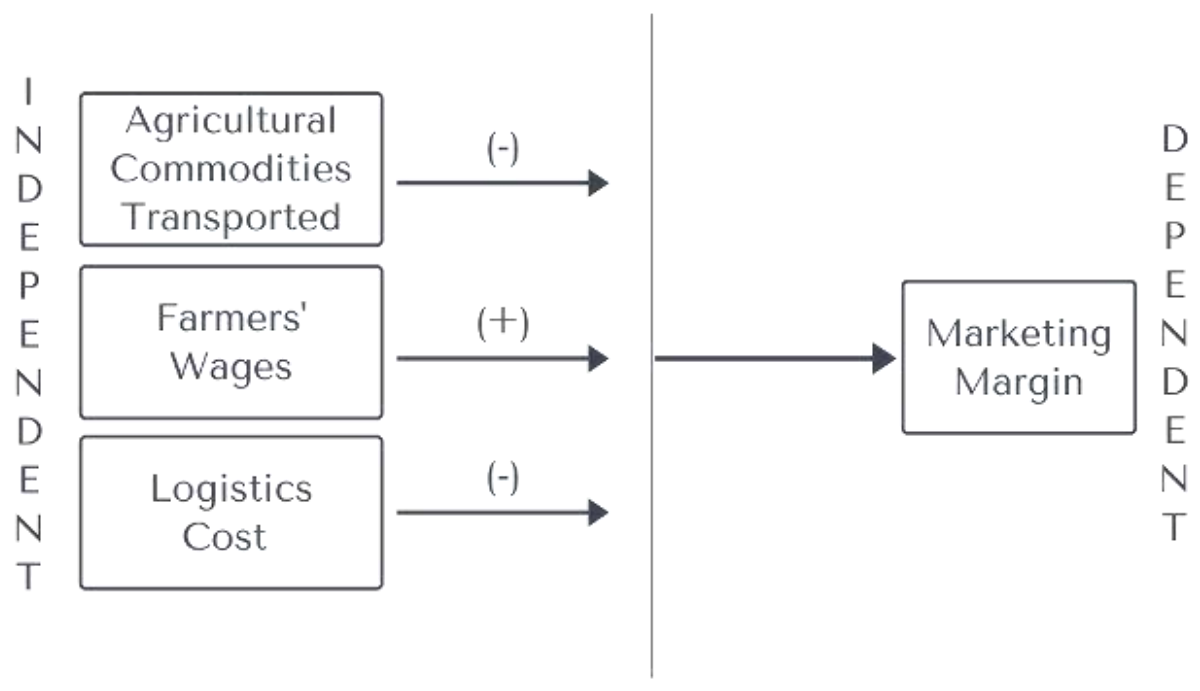

\subsection{Statement of Objectives}

The objective of this study was to identify how exogenous variables affect marketing margin. There were three primary objectives of this study:

1. To identify the relationship between Agricultural Commodities Transported to Marketing Margin.

2. To identify the relationship between Farmers' Wages to Marketing Margin.

3. To identify the relationship between Logistics costs to Marketing Margin.

\subsection{Statement of Hypothesis}

Hypothesis 1:

Ho: Agriculture Commodities Transported have no significant impact on the Marketing Margin.

Ha: Agriculture Commodities Transported have a significant impact on the Marketing Margin.

Hypothesis 2:

Ho: Farmers' Wages have no significant impact on the Marketing Margin.

Ha: Farmers' Wages have a significant impact on the Marketing Margin. 
Hypothesis 3:

Ho: Logistics Cost has no significant impact on the Marketing Margin.

Ha: Logistics Cost has a significant impact on the Marketing Margin.

\subsection{Scope and Limitations}

The paper's course of the discussion focused on analyzing the farmers' wage, logistics cost, and impact of middlemen involvement through farm-retail price spread. The paper covered the country's historical yearly commodity flow, agricultural wage rates, and consumer price index from the year 1995-2019.

The researchers averaged the available agricultural commodities included in computing the Farmgate and Retail prices such as Beans and Legumes, Cereals, Condiments, Fruit Vegetables, Fruits, Leafy Vegetables, Livestock, Poultry, and Root Crops to minimize discrepancies due to missing data. Additionally, the logistics variable used in this paper was the logistics cost proxied by the Consumer Price Index (CPI) of transportation services.

\subsection{Significance of the Study}

This paper expanded and reconciled results from various studies, primarily on Marketing Margins. It aimed to analyze the impact of logistics costs and farmers' wages on marketing margin. The analytical framework developed by Wohlgenant (2001) has given a fundamental knowledge of how marketing margins behave when affected by various external factors. The researchers attempted to explore the effects of other variables with respect to Wohlgenant's theory. Lastly, this research mainly contributed to the applied field of Agricultural Economics.

\section{Literature Review}

\subsection{Marketing Margin}

In marketing studies, marketing margins and costs are essential in understanding how the modifications are done in marketing systems. It determines the efficiency and the portion contributed by the consumer for the agricultural good. The margin represents the difference between the producer gate's sale price and the consumer purchase price for the same commodity (Jassam et al., 2018). As defined by Wohlgenant (2001) and Gardner (1975), "the concept of marketing margin, or farm-to-retail price spread, was developed to measure the cost of providing a bundle of marketing services. Although there are many ways to characterize the marketing margin, it is best viewed like price as an equilibrium entity defined as some function of the difference between equilibrium retail price and equilibrium farm price of a given farm product. The price spread may be measured by the difference between the retail and farm price or by the percentage marketing margin, (Px - Pa)/Pa.". Middlemen have a function in collecting, grading, storage, distributing, and selling in marketing channels. The impact of middlemen on vegetable marketing channels was measured by using the marketing margin, which is the difference between the price paid by the end consumer and the price received by the farmer or producer (Sandika, 2012).

Nuthalapati et al. (2020) analyzed the impact of supermarkets on farmgate prices and stated that selling in supermarkets has a significantly lower marketing margin compared to selling in traditional markets. In agricultural markets, asymmetric price transmission, unstable farmgate prices, and a poor relationship between farmgate and retail prices have been observed (Russo $\&$ Goodhue, 2017). Rivera-Padilla (2020) suggested that farmers can enter and thrive in profitable agricultural markets by reducing transaction costs and creating competitive markets. Moreover, Traub and Jayne (2008) explored the effects of market reform of milling or retail margins; however, they could not determine the causes of high margins and why marketing liberalization has failed to reduce marketing margins. It would be improbable that marketing margins would rise proportionately if prices of food commodities increase as well, and as an alternative, assuming that marketing margins are fixed in absolute terms is a more reasonable predictor than proportionality (Dawe \& Maltsoglou, 2014). Dawe et al. (2008) compared the rice marketing margin in the Philippines and Thailand. Although these two countries have many similarities between their systems, the Philippines have a more competitive structure, and its rice marking margin is more significant than Thailand.

Sandika (2012) measured the impact of middlemen on commodities by using their marketing margin. With the presence of costs and expenses in the market, only a small number of farmers are willing to engage in logistics with their agricultural products' transportation (Yuzhou, 2020). Abebe et al. (2015) stated that distribution channels and farmers would rely on middlemen if any form of unreliability in the transaction market occurs. The study of Piabuo et al. (2020) found that many studies have investigated why farmers tend to use middlemen due to high transportation costs, making it difficult for farmers to sell to end consumers directly and due to insufficient market information. Usually, farmers are only informed about the distribution prices while the middlemen have a more excellent knowledge of the market price. Therefore, it causes the farmer to either transact with a middleman or engage himself in the market but face high transportation costs. Middlemen can be both helpful and exploitative at the same time (Mitchell, 2011). 
It is important to note that middlemen are perceived to be exploitative since there is asymmetric information between the farm employees and the market. The middlemen exploit this gap and are an advantage to generate large commissions (Pokhrel \& Thapa, 2007). The availability of market information is vital to the farmers in the production process because they can clearly understand the consumers' demands through this. However, this is not always the case for farmers, and it is where the role of middlemen comes into play. The perception is that the rural farmers use middlemen's services because these intermediaries have better access to the demands of the consumers in the urban area. Farmers who are closest to a market are less likely to rely on middlemen, and they are well placed to attract a buyer because one or more wholesalers are more likely to visit them (Abebe et al., 2015).

The relationship between farmers and the market intermediaries is affected by insufficient market information and understanding regarding the goods needed by the consumers, which can distort the market (Digal et al., 2006). It is common for developing countries to have market failure in the food chain, making middlemen necessary market information providers and associating themselves in the negotiation between farmers and retailers. The middlemen can also lessen the search costs in markets for the farmers. The middleman is the one who intermediates between farmer and wholesaler, wherein it serves as a binary channel choice decision problem that maximizes the utility of the farmers (Abebe et al., 2015). "In economic theory, the main function of institutions is to minimize transaction costs (North, 1994; Platteau, 1994; Williamson, 1998). The transaction cost literature considers the institution of middlemen as a cost-reducing arrangement between sellers and buyers (Landa, 1981). Middlemen can economize on direct exchange costs, for example, by facilitating a match between a buyer and a seller (Biglaiser \& Friedman, 1999) and by decreasing transaction costs related to search time and information asymmetry (Dixit, 2009; Hayami, 1996)." as cited by Abebe et al. (2015).

\subsection{Agricultural Commodities Transported to Marketing Margin}

The agricultural commodity supply chain is an economic structure in which the gains and costs are distributed among its participants, and if there is incompetence on the part of the food production, this may result in the value of the distributed product declining on both quality and quantity (Perdana, 2012). Edeme et al. (2020) hypothesized that transport infrastructure has a negative and insignificant impact on agricultural output. Gollin and Rogerson (2014) hypothesized that low productivity in logistics leads to higher labour allocation in agriculture. Farmers are more encouraged to increase their production size and improve yield and product quality because of transportation effectiveness, and this enables agricultural workers to market their agricultural products quickly and directly (Yuzhou, 2020). As the volume of production of a farmer becomes high, there is a likelihood for that farmer to use intermediaries. However, small-time farmers would not engage in intermediation as it entails greater price risk. Farmers can sell their goods in nearby markets or sell at farm gates and enable them to earn the market price that has less shipping and handling costs by selling in local markets (Abebe et al., 2015).

Camisón-Haba and Clemente-Almendros (2020) studied the determinants of transport costs and found that distance is not the most effective way to determine transportation costs. Whereas it is more significant to decide on the degree of competition between logistics operators on the route, the economies of scale derived from the volume of freight flow and the volume of commodities transported on the route, the supply chain structure, the business strategy, and the range and quality of transportation infrastructure. Tomatoes and lettuce are rarely delivered to Metro Manila because of intense competition from produce grown in Benguet. Mindanao tomatoes and lettuce are usually sold only in the Visayas, specifically in Bacolod and Cebu's cities. However, when a typhoon strikes in Luzon's cropping areas, Mindanao tomatoes and lettuce make their way into Luzon's markets, mainly in Metro Manila (Llanto et al., 2012). Agricultural products and postharvest handling and storage have been described as steps in the food supply chain with comparatively high food losses in the Philippines. Agricultural commodities are typically shipped from the southern to the northern parts of the Philippines, where most agricultural produce was traded, and the transit time is usually about thirty-six (36) hours. If transportation is delayed, farmers face increased handling costs, volume loss, and possible sales loss (Mopera, 2016).

The transport time and distance from the farms to retail stores is far, the number of agricultural goods being transported can be limited because of the size of containers, one-way haulage of agricultural commodities, and the spoilage of the outputs during transport. There are restrictions related to the flow and storage of products and services in food and agribusiness in developed countries, such as a lack of sufficient storage facilities and knowledge of dealing, inadequate manufacturing, administration, and transportation services. The development of effective and efficient agricultural and food logistics is a critical component (Gebresenbet \& Bosona, 2012). Therefore, the usual occurrence of one-way and empty haulage can be an onerous element in the agricultural sector as this lowers the maximization of the vehicles travelling from and to their destination (Wajszczuk, 2016).

Food production has become more productive in recent years as a result of technological advancements and processes in agriculture (Clements, 2010). The system of food processing and distribution is heavily influenced by transportation. Transportation is considered an important factor in increasing farm production. It improves people's quality of life, builds opportunities for agricultural goods to be promoted, encourages interaction among regions and introduces new sectors as an economic focus 
(Ajiboye \& Afolayan, 2009). Food wastage is more prevalent upstream in developing countries, such as agricultural production, postharvest handling, and storage. Simultaneously, it is more prevalent downstream in developed countries in terms of production, distribution, transportation, and consumption (Mopera, 2016).

Liu et al. (2018) mentioned that agricultural products are commonly distributed in advantageous areas to increase sellers' and consumers' gaps. In this manner, to meet customer needs, it had to supply goods to the point of consumption through "transportation.". Yuzhou (2020) stated that when farmers directly sell their agricultural products to buyers, it can improve agricultural logistics efficiency as products are transported relatively quickly. Jassam et al. (2018) insisted on the need to produce and market agricultural commodities. The production of agricultural goods is concerned with how farmers can sell these products to the end consumers. Transport is commonly identified as an essential factor in agricultural production globally. It is the only way for food grown on farms to be delivered to various homes and markets.

Transport builds markets for agricultural commodities, increases connectivity between geographical and industrial regions, and opens up new economic target areas (Tunde \& Adeniyi, 2012). Transportation is recognized to be the only means of transferring a good from one area to another. It contributes significantly to farmers' livelihood in rural areas as their role in distributing agricultural goods improves people's quality of life (Afolabi et al., 2018). Michail \& Melas (2021) examined the changes in agricultural commodity price and their effect on transportation systems and discovered that not all agricultural goods have the same impact on transportation costs due to distinguishing factors such as perishability and seasonality. Ongkunaruk \& Piyakarn (2011) concluded that logistics costs vary depending on the farm size because the yield of a commodity increases along with the farm size.

Transporting agricultural commodities is a substantial aspect in increasing the quantity produced in the production (Gebresenbet \& Bosona, 2012). According to Carambas (2005), to maximize production supply, the use of marketing inputs can be rather used, and in turn, this would increase the prices faced by the consumers or the retail prices more than farmgate prices leading to higher marketing margins. Thus, under the assumption of variable input proportion, the marketing margin decreases as the quantity of farm products increases. However, as Gardner (1975) argued, using substitutes for marketing inputs can be an alternative if the supplies of this input are more elastic than other inputs. In this circumstance, the prices of marketing inputs do not increase substantially in response to the rising demand for such indicators and enable the price ratio to decline. Wohlgenant (2001) mentioned that the relationship between marketing margins and quantity would be positive given the assumption of fixed input proportions. However, empirical evidence from the studies of Buse and Brandow (1960), Waugh (1964), George and King (1971), and Tomek and Robinson (1990) showed a negative relationship which is consistent with the assumption of the variable input proportions as cited by Abassian et al. (2010).

Adamopoulos (2011) argued when the labour productivity in transportation is low, costs in transporting final goods and intermediate inputs across regions increase; thus, market margin increases. Camisón-Haba and Clemente-Almendros (2020) hypothesized and concluded that transport costs decrease if a company increases its freight volume and the average shipment size. Therefore, when the volume of commodities transported increases, the marketing margin decreases. Farmers' productivity and welfare are directly affected by improved transportation because when market access is limited, farmers pay high prices for their purchases and receive low prices for their sales (Sotelo, 2019). Zant (2018) analyzed the impact of rail transport on the market price of agricultural commodities. The author was able to determine that low transport costs improve agricultural commodity trade in markets.

Moreover, Gardner (1975) stated that by decreasing the price of farmers' marketing activities, it is possible for the marketing margin or price spread to decrease as the supply of farm commodities increases. Nwaigwe et al. (2019) mentioned that despite increasing marketing margins, the commodity involved in their study remained inefficient and came up with an analysis that the functionality of agricultural marketing systems is essential to obtain accuracy in the prices paid by traders. Over the years, agricultural commodity prices have appeared to be volatile. Moreso, the instability and uncertainties in the supply side with the rise in global food prices, which is a possible reason for the upsurge of farm prices, would continue to emerge (Bayramoglu, 2014).

\subsection{Farmers' Wages to Marketing Margin}

In terms of exporting goods, farmers have a range of choices. They may sell through middlemen, transport their goods to the market directly or form a group. A number of factors influence the farmer's decision to select one of the above alternatives. Owing to a lack of consumer knowledge and comparatively limited information, some farmers choose to sell through middlemen (Piabuo et al., 2020). Negi et al. (2018) proposed that although there is a positive effect of improved market access on price realization from informal traders, a change in the farmer-trader relationship is unlikely to significantly change due to related transactions comprising inputs, credit, and outputs. Moreover, the authors were able to find out that small-scale farmers are more reliant on traders and middlemen due to limited and costly access to transport and communication networks thus, selling their produce at a 
lower price. Using the Concurrent Marketing Margin Analysis approach, Mandizvidza (2017) found that due to marketing intermediaries' intervention, the amount that farmers receive from the consumers' purchasing power is lower.

Middlemen generate revenue by intervening in the transaction, but they also cause complications. Importing agricultural goods may impose a threat on the price of domestically produced farm goods. The difficulty of balancing the supply and demand is usually in the production process due to the volatile influences of climate, immediacy, and perishability of the commodities (Yuzhou, 2020). Several farmers have a slight chance of alleviating their situation as the possible marketing activities are unable to fully perform their capacities due to incompetent transport conditions (Gebresenbet \& Bosona, 2012). Binswanger and Singh (2017) stated that structural change triggers a reduction in the agricultural sector's share of production and labor, as well as a rise in the productivity gap, and until the economies develop, it can converge at low levels.

Gardner (1975) showed different cases on how farmers' income may respond to changes in demand and supply. For instance, a rise in the service industry's wage rate or an increase in the price of petroleum can both cause an upward shift to the supply curve of marketing inputs, thereby increasing the marketing margin (Fisher, 1981). In the study made by Verma (2010), she assessed the impacts of commodities when prices are volatile and used the Philippines as one of her variables. In the Philippines, the author stated that returns to agricultural factors fall, as do unskilled wages. Rising wages are correlated with decreased crop production, ceteris paribus (Binswanger \& Singh, 2017). Carambas (2005) affirmed that under the presumption of variable input proportion, the correlation of marketing margin to marketing input prices such as wages is positive. It is important for the wage of farmers in agricultural production to be addressed. Therefore, increasing the agricultural prices is needed to raise the wage of farm employees as a whole (Yuzhou, 2020).

It is often mentioned that middlemen are generally in a better marketing position for they have a greater understanding of marketing conditions in both farm and retail markets. Also, due to the intervening factor of middlemen, the farmers receive a lower proportion from the marketing margin due to the longer distribution channel (Abebe et al., 2015). Despite the increase in farm and retail price spread, farmers can still increase the profit and wage they receive if some production techniques are applied, such as the right mix of inputs and reducing outputs (Aguinaldo et al., 2016). Mandizvidza (2017) emphasized that farmers receive less from their share in the transaction with the presence of a high marketing margin. There was a significant price and profit gap in vegetable farmers who sell directly to the consumer and those who sell through middlemen (Piabuo et al., 2020). Better access to market information increases the probability that farmers will earn higher rates from middlemen, increasing their profits and enabling them to make better production decisions. Also, if the level of competition between middlemen is strong and transfer cost is low, the farmer does not need to understand the market price to get a good bid from the middleman (Mitchell, 2011). Suppose a distribution network is in place, the practices of middlemen who buy from farmers at low prices and then hoard to establish artificial scarcity in order to market at higher prices will be eliminated completely or significantly diminished (Oguoma, 2010).

Traub and Jayne (2008) stated that marketing costs serve as a bridge between the prices farmers earn and the price consumers pay. When marketing costs rise, there is inevitably one of two outcomes: prices to farmers decrease, or consumer prices increase. In which they concluded that an increase in real wage rates is seen to increase market margins. Strategies that effectively bring down costs within the marketing system could raise farmer incomes, improve underprivileged people's food security and disposable incomes, and promote the kinds of structural transformation processes that have supported economic development in other developing countries (Johnston \& Kilby, 1975; Mellor, 1976, as cited by Traub \& Jayne, 2008). As the price of wage products increases, industries that depend heavily on labor tend to have higher prices, which has a cascading impact across the economy, including a loss of competitiveness in foreign markets (Delgado, 1992, as cited by Traub \& Jayne, 2008). Based on the study of Nuthalapati et al. (2020), supermarkets can pay higher prices to farmers because of the lower marketing margin. In contrast, Gollin and Rogerson (2014) concluded that income levels are low when transaction costs are high.

\subsection{Logistics Cost to Marketing Margin}

Catalbas (2012) states that the structure of economics of logistics was established due to the intertwined relationship between economics and logistics. Principles in Economics served as the foundation of Economics of Logistics, wherein firms would want to maximize their returns at the least possible cost when supplying the needs of consumers while being affected by factors such as productivity, expenses, and economic growth. Agri-Food logistics is an important part of the economy. It is composed of a logistics flow mechanism, starting from production to transportation and storage until the end consumer (Wajszczuk, 2016).

Stainer (1997) addressed productivity and performance measurement and management in logistics. He stated that logistics are considered the link between production and marketing within the supply chain. There is also a need for productive and effective performance in supply chains or logistics systems for organizations to survive and profit. Logistics productivity should be at the center of every country's policies to ensure effectiveness in the process (Jhawar et al., 2017). Randall and Farris (2009) stated that supply chain improvements could generate larger profits and revenue. Logistics service providers are essential in logistics chain 
efficiency as other areas in the process also depend on it, such as distributing the goods and obtaining raw materials (Ceniga $\&$ Sukalova, 2015).

The study of Silva et al. (2014) indicated that whenever logistics cost is involved, it refers to transportation costs and a frequently recognized component. Piabuo et al. (2020) noted that farmers bear the costs in production while the middlemen bear costs in transportation. A study by Fang - asan et al. (2009), dealing with "commissioners" became the most common marketing arrangement due to inadequate transportation networks and services, as well as a lack of a local market. In Guritno (2015) study, at each level of logistics costs, material handling logistics is the most dominant operation and accounts for the highest proportion of all logistics costs. The cost of transportation is also a significant percentage of the cost for producers and retailers.

Logistics costs are primarily considered as indirect costs because they are not strictly related to basic goods (Bokor \& MarkovitsSomogyi, 2011). Silva et al. (2014) mentioned that logistics cost management is a vast and dynamic term that includes a wide variety of logistics operations such as transportation, delivery, and storage. A logistics network is essential to have an effective supply chain and, as a result, reduce costs and improve its service (Yuzhou, 2020). Transportation that is efficient and productive serves as one of the networks for the gathering and distributing goods and services, the movement of persons, the transmission of information, and the development of the agriculture sector (Afolabi et al., 2018). Costs of transportation and connectivity have declined due to technological advancements such as containers and the internet. Refrigerated containers and air transportation also enabled perishable farm goods to enter far-flung markets, allowing customers to enjoy seasonal foods all year. All along the supply chain, progress has been made to ensure a seamless delivery of goods and services (Liapis \& Tsigas, 2014).

Granillo-Macías et al. (2018) mentioned that transportation costs have a major contribution to the systems of logistics cost, which significantly affects the productivity of farm employees who are part of the agri-food supply chain. Zant (2018) stated that high transportation costs make trade unprofitable, forcing farmers to rely on subsistence farming. Fresh agricultural commodity logistics costs and the logistics management process of human and material resources are essential for the logistics cost. As society develops, human capital costs rise, increasing logistics costs (Han, 2017). The cost of transporting agricultural goods from farms to markets significantly impacts farmer productivity and profits. This is because agricultural product transportation costs vary depending on the type of commodity, the transport's efficiency and the distance travelled (Tunde \& Adeniyi, 2012). According to Oyewole (1976) cited in Asogwa et al. (2012), the key factors of high prices in selling agricultural goods are transportation and storage costs and losses due to spoilage. Value-adding or storage will extend these goods' shelf life, decreasing the possibility of food loss (Mopera, 2016).

Tseng et al. (2005) asserted that since transportation is the highest contributor to the logistics system's cost, its productivity can improve logistics performance. The majority of research on the logistics cost of fresh agricultural goods has focused on fundamental economic analysis. As a result, research keeping a crop fresh is becoming increasingly relevant in the agricultural supply chain network. New agricultural food supply chains are distinguished from other commodity supply chains (Shang et al., 2014). Long supply lead times, supply and demand uncertainty, and narrow margins are three characteristics of the fresh fruit supply chain. These characteristics necessitate logistics management efficiency (Ferro et al., 2015). Gu and Dong (2016) mentioned that one cause of high logistics costs is that firms may not consider a company's supply chain processes, thus, inefficiency in logistics systems.

Logistics is considered an expensive sector requiring considerable expenditures to maintain its service (Park \& Lee, 2015). However, the output produced in the service sector is usually not tangible, which makes it harder to quantify; thus, a proxy method for productivity indicator can be utilized (Stainer, 1997). According to Adamopoulos (2011), logistics costs data are difficult to gather and are usually not available on a systematic basis for a significant number of countries, including developing countries. Due to data constraints, Lean et al. (2014) used different proxies for the logistics variables such as the real output of transportation, warehousing and communications industry and the price for logistics is proxied by consumer price index (CPI). There are not enough studies on the logistics sector in the economics literature. One of the primary reasons for this is the lack of analytical evidence on logistics that might serve as the foundation for such studies (Sezer \& Abasiz, 2017).

The costs that entail agri-food commodities production are the main constraint for farmers, but this also measures production (Yuzhou, 2020). As cited by Hadi (1990), Campbell and Fisher (1982) mentioned that marketing margins directly correlate with marketing costs, and one of the sources of these rising costs could be increased transportation costs. However, as Tomek and Robinson (1981) indicate, marketing costs can also decline with economies of scale, such as improvements in the production process. It is more efficient if the farmer price level increases and the retail price level decreases by lessening marketing intermediaries (Salam \& Sakia, 2021).

In food production, parties involved in the transaction encounter expenses. The produced goods of farms and logistics costs can positively affect profits in agriculture (Yuzhou, 2020). Since fresh agricultural products on transport and storage have higher requirements, fresh agricultural products in the entire logistics system costs significantly increased (Han, 2017). Mérel et al. (2006) 
addressed in their paper on reducing transportation costs leads to an opportunity to have higher farm-level prices. They were able to analyze that having better transportation results in lower logistics cost and higher productivity with regards to higher farm prices.

According to the study of Carambas (2005), from the analysis conducted by Wohlgenant and Mullen (1987), Marsh (1991), Lyon and Thompson (1993), and Richards et al. (1996) are all unanimous in affirming that generally, costs in marketing is directly correlated to marketing margins. Additionally, in terms of relative prices, the increase in output and marketing costs is expected to lower the farm-retail price ratio (Wohlgenant $\&$ Mullen, 1987). Nonetheless, in absolute prices, increases in both output and marketing costs cause a greater price spread (Wohlgenant \& Mullen, 1987) as put forth by Gardner (1975). Assuming that farmgate and retail prices rise by the same amount, as is almost uniformly believed, marketing costs rise by the same percentage as well (Dawe \& Maltsoglou, 2014). Even with high production costs for agricultural goods, it still results in higher margins (Aguinaldo et al., 2016). Gollin and Rogerson (2014) stated that food becomes more expensive in urban areas than in rural areas when transport costs increase, which means marketing margin increases. Oguoma (2010) stated that each intermediary contributes an expense to the deal, and the more middlemen there are, the greater the sales cost. Ebarle (2013) found that marketing intermediaries can compensate for the high costs incurred due to transportation and storage by increasing prices, and so does the marketing margin.

Logistics costs components are the cost of the product and the selling price of products; whereas the cost is high, then the price of agricultural products is also high. Each chain logistics system devises the total logistics cost charged to the product being sold (Parung et al., 2015). High transportation costs equate to a high sale price, and if the price is too high compared to other farmers, buyers would not buy and might lead to a loss (Tunde \& Adeniyi, 2012). On the other hand, Zant (2018) stated low transportation costs increase trade, lower prices and price dispersion, and provide farmers with incentives to commercialize. Low transportation costs increase supply response, allocative efficiency, technology adoption and innovation, and economic growth in the long run.

\section{Methodology}

\subsection{Research Design}

The study used a descriptive-quantitative approach in determining the relationship between the variables involved. Using Ordinary Least Squares (OLS) regression analysis along with diagnostic tests such as Unit Root, Autocorrelation, Normality of Residuals, Specification Error, Multicollinearity, Heteroskedasticity, and Stability as the econometric measurements. These are proved to be suitable as Sandika (2012), Mitra et al. (2018), Sezer and Abasiz (2017) and Lean et al. (2014) applied this type of methodology in their studies.

\subsection{Study Site}

The area of the study is in the Philippines at a national level. The researchers chose time series data, and its annual frequency spanned the period of 1995-2019.

\subsection{Data Collection Procedure}

This study was done by gathering secondary data. Agricultural Commodities Transported, Farmers' Wages, and Logistics Cost are all collected from Philippine Statistics Authority. The following would be the variables and their respective measurements: (1) Agricultural Commodities Transported was measured by the quantity of food and live animals by mode of transport (2) Farmers' Wages was measured by agricultural wage rates of farm workers (3) Logistics Cost was measured by the price of logistics as proxied by the CPI for transport services as done by Lean et al. (2014) due to data constraints in logistics. (4) Marketing Margin was measured by the average prices of Farmgate and Retail commodities. The agricultural commodities are Beans and Legumes, Cereals, Condiments, Fruit Vegetables, Fruits, Leafy Vegetables, Livestock, Poultry, and Root Crops. Each commodity includes its different varieties.

\subsection{Data Analysis}

\subsubsection{Marketing Margin}

The impact of middlemen on agricultural commodities marketing channels was calculated by considering the Marketing Margin (MM) of the middlemen. Marketing Margin (MM) is the difference between the retail price and farm value (Sandika, 2012). In this case, the margin is typically the profit made under a given market condition (FAO, 2011). The marketing Margin of middlemen was measured by adopting the following equation provided by Gardner (1975):

$$
M M=\underline{R P}-P P
$$

Where:

$\mathrm{MM}=$ Marketing Margin 


$$
\begin{aligned}
& \mathrm{RP}=\text { Retail Price } \\
& \mathrm{PP}=\text { Producer Price }
\end{aligned}
$$

\subsubsection{Econometric Model}

The objective of this paper was to identify how exogenous variables such as logistics and wages affect the marketing margin. Gardner (1975) and Wohlgenant (2001) provided similar findings that showed how external factors impact marketing margin. The researchers also wanted to seek if the effects of these variables correlate to the previous authors' findings. The researchers used a multivariable regression model to measure and quantify the results for the analysis represented by the econometric model provided below. The model helped identify whether to accept or refute the hypothesis suggested in the first chapter of this study.

$$
M M=-\beta O-\beta 1 A C T+\beta 2 F W-\beta 3 L C+\varepsilon
$$

Where:

$$
\begin{aligned}
& M M=\text { Marketing Margin } \\
& A C T=\text { Agriculture Commodities Transported } \\
& F W=\text { Farmers' Wages } \\
& L C=\text { Logistics Cost } \\
& \beta O=\text { Constant term or intercept } \\
& \beta 1=\text { Beta Coefficient of Agriculture Commodities Transported } \\
& \beta 2=\text { Beta Coefficient of Farmers' Wages } \\
& \beta 3=\text { Beta Coefficient of Logistics Cost } \\
& \varepsilon=\text { Error Term }
\end{aligned}
$$

\subsection{Diagnostic Tests}

\subsubsection{Test for Unit Root}

The Augmented Dickey-Fuller is used to test the stationarity of the variables. This test is conducted by "augmenting" the preceding three equations by adding the lagged values of the dependent variable $\Delta Y \mathrm{Yt}$. At the formal level, stationarity can be checked by finding out if the time series contains a unit root. The Dickey-Fuller (DF) and augmented Dickey-Fuller (ADF) tests can be used for this purpose (Gujarati, 2004). To avoid spurious results, the ADF is a necessary test to undertake in the regression (Lean et al., 2014).

\subsubsection{Test for Autocorrelation}

Autocorrelation refers to when one observation in an equation is time-dependent on a past or potential observation. For example, first-order autocorrelation occurs where an observation in a time series is compared to the previous observation. This effect has been widely researched and discovered to exist in commodities and prices (Clements, 2010). The Durbin-Watson is calculated for $\mathrm{h}$ lags, and the Durbin-Watson test is calculated only for lag 1. Thus, any autocorrelation beyond lag 1 will not be detected by this test (Mahan et al., 2015). To avoid some of the pitfalls of the Durbin-Watson d test of autocorrelation, statisticians Breusch and Godfrey have developed a test of autocorrelation that is general in the sense that it allows for (1) nonstochastic regressors, such as the lagged values of the regressand; (2) higher-order autoregressive schemes, such as $\operatorname{AR}(1)$, $A R(2)$, etc.; and (3) simple or higherorder moving averages of white noise error terms (Gujarati, 2004).

\subsubsection{Test for Normality of Residuals}

The Jarque - Bera (JB) Test of Normality is considered as an asymptotic or large-sample test which is also based on the residuals of the Ordinary Least Squares (OLS). The test primarily computes the scenes and kurtosis measures of the OLS residuals (Gujarati, 2004).

\subsubsection{Test for Specification Error}

Regression Specification Error Test or Ramsey's RESET test will be used for the linear regression model wherein the said test is used to test different specification errors such as incorrect functional form, redundant and omitted variables (Gujarati, 2004).

\subsubsection{Test for Multicollinearity}

Multicollinearity arises when two or more variables display an almost perfect or exact linear relationship among each other and is often encountered when doing OLS regression. One of the purposes of regression is to determine to what extent the independent 
variable can predict the outcome. The Variance Inflation Factor (VIF) will be used to assess the presence of multicollinearity. Furthermore, if the predictors are correlated, it can determine how much the variance of an expected regression coefficient increases. The VIFs would all be 1 if no variables are associated (Calicdan et al., 2020). This problem skews the significance levels of independent variables and inflates standard errors. It does not affect the model's fit, but it can make each of the independent variables less accurate (Clements, 2010).

\subsubsection{Test for Heteroskedasticity}

The Breusch-Pagan test was used to check whether the estimated variance of residuals from regression is dependent on the values of the independent variables (Calicdan et al., 2020). There is a presence of Heteroskedasticity if the variance of the error term is constant for all observations do not hold, which is an assumption of the Ordinary Least Squares (OLS) (Salvatore \& Reagle, 2002).

White-Heteroskedasticity test was used to test if the regression residuals have unequal variances. The general test of Heteroskedasticity, as proposed by White, does not rely on the normality assumption and is much easier to implement (Gujarati, 2004).

\subsubsection{Test for Stability}

Structural changes possibly caused by differences in the intercept or the slope coefficient or both are characterized by the Chow Breakpoint Test (Gujarati, 2004). The model uses F-test in order to test which of the two regressions is more efficient: single regression and two separate regressions, which involve splitting the data into two sub-samples. Wherein, if the calculated f-ratio exceeds the critical value, the null hypothesis structural stability can be ruled out; otherwise, the null hypothesis is accepted (Calicdan et al., 2020).

\section{Results and Discussion}

\subsubsection{Descriptive Results}

The graphs provided below show the historical trends of the variables used in the study using the years 1995 to 2019 . The Farmers' Wages and Logistics Cost both exhibit an upward trend. However, Farmers' Wages have shown a stable state from 1995 to 2011 , then increased steadily in the following years. Conversely, the Agricultural Commodities Transported has exhibited fluctuations over time. The Marketing Margin displayed fluctuation throughout the years, but from 2008 to 2013, there has been a downward movement although it continued to rise from 2014 onwards.

FW

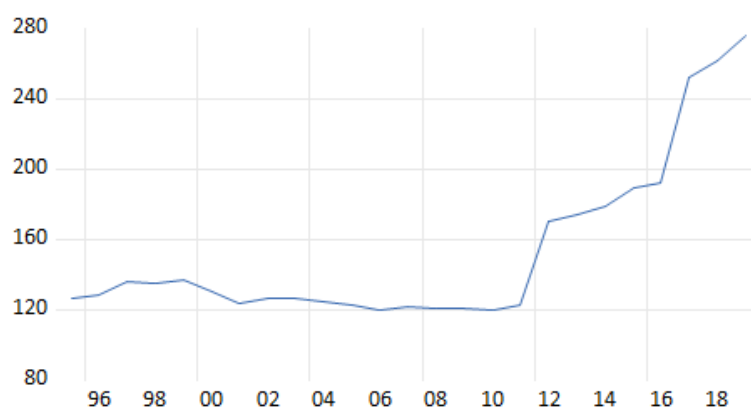

$\mathrm{ACT}$

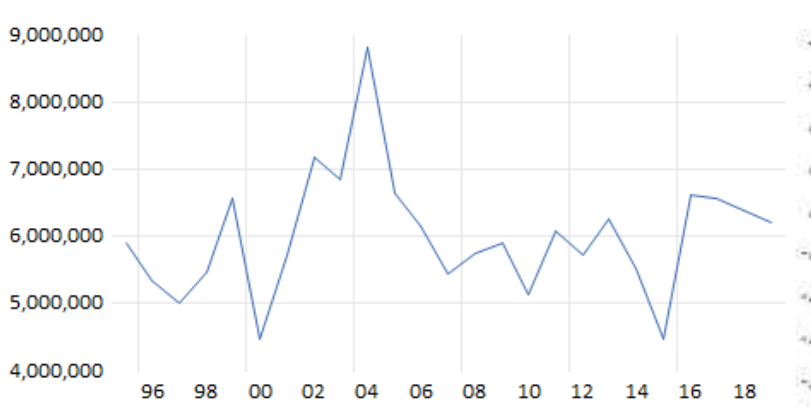

LC

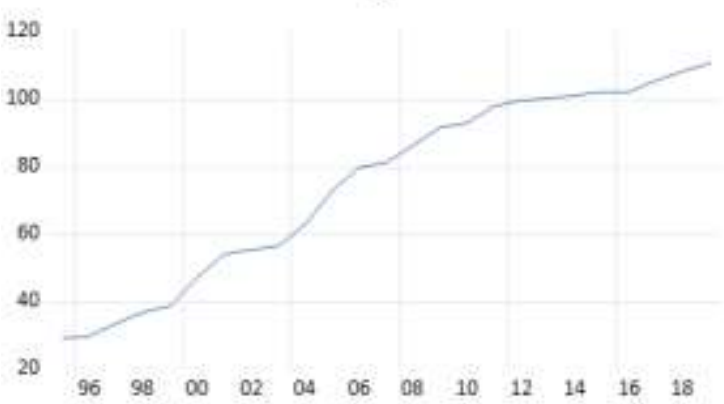

$M M$

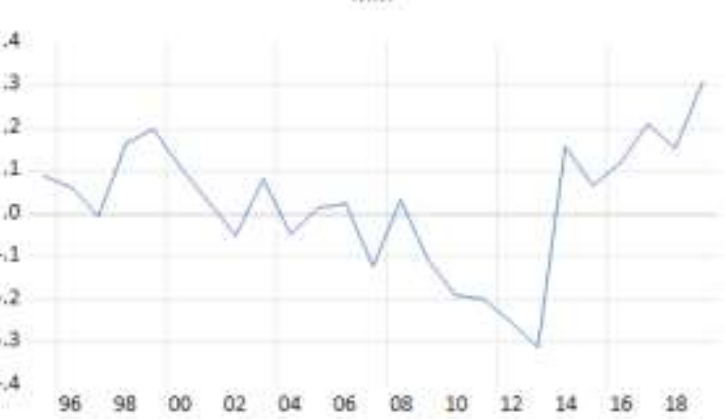




\subsubsection{Numerical Results}

Figure 4.1.2

\section{Ordinary Least Squares (OLS) Regression Procedure Result}

\begin{tabular}{|c|c|c|c|c|}
\hline Variable & Coefficient & Std. Error & t-Statistic & Prob. \\
\hline C & -0.121009 & 0.171905 & -0.703932 & 0.4892 \\
\hline ACT & $-1.41 \mathrm{E}-09$ & $2.59 \mathrm{E}-08$ & -0.054587 & 0.9570 \\
\hline FW & 0.002818 & 0.000618 & 4.557425 & 0.0002 \\
\hline LC & -0.003741 & 0.001047 & -3.571854 & 0.0018 \\
\hline R-squared & 0.509863 & \multicolumn{2}{|c|}{ Mean dependent var } & 0.021131 \\
\hline Adjusted R-squared & 0.439844 & \multicolumn{2}{|c|}{ S.D. dependent var } & 0.152698 \\
\hline S.E. of regression & 0.114284 & \multicolumn{2}{|c|}{ Akaike info criterion } & -1.354607 \\
\hline Sum squared resid & 0.274279 & \multicolumn{2}{|c|}{ Schwarz criterion } & -1.159587 \\
\hline Log likelihood & 20.93259 & \multicolumn{2}{|c|}{ Hannan-Quinn criter. } & -1.300517 \\
\hline F-statistic & 7.281726 & \multirow{2}{*}{\multicolumn{2}{|c|}{ Durbin-Watson stat }} & 1.641326 \\
\hline Prob(F-statistic) & 0.001575 & & & \\
\hline
\end{tabular}

Figure 4.1.2 presents the multiple regression results of the variables affecting Marketing Margin from 1995-2019, for a total of 25 observations. The overall significance (Prob F-statistic) of the regression is statistically significant with a p-value of 0.0015 , which is less than $5 \%$ significance level. The variables Farmers' Wages and Logistics Cost are both statistically significant at $5 \%$ significance level. However, the Agricultural Commodities Transported was statistically insignificant. With the specified level of significance, $\mathrm{p}$ values of Farmers' Wages and Logistics Cost indicate that these variables are statistically significant, which leads to the acceptance of the alternative hypothesis that Farmers' Wages and Logistics Cost have a significant impact on the Marketing Margin.

Based on the statistical results of the OLS regression, the econometric model equation was specified as:

$$
\mathrm{MM}=-0.121009-1.41 \mathrm{E}-09(\mathrm{ACT})+0.002818(\mathrm{FW})-0.003741(\mathrm{LC})+\varepsilon
$$

The model suggests that the marketing margin is -0.121009 if all independent variables remain zero. Marketing margin will decrease by $1.41 \mathrm{E}-09$ for every unit increase in the agricultural commodities transported. Additionally, the marketing margin will increase by 0.002818 if farmers' wages expand by one unit. Furthermore, the marketing margin will decrease by 0.003741 for every unit increase in the logistics cost.

Table 4.1.2

\section{Diagnostic Tests}

Indicated below is the summarized result of the diagnostic tests:

\begin{tabular}{|c|c|c|c|c|c|}
\hline DIAGNOSTIC TESTS & \multicolumn{5}{|c|}{ RESULT } \\
\hline \multirow{11}{*}{ Unit Root (Augmented Dickey-Fuller) } & & & \multicolumn{3}{|c|}{ Test Critical Values } \\
\hline & VARIABLES & ADF t-stat & 1X level & $5 \times$ level & $10 \%$ level \\
\hline & Level: ACT & -3.46 & -3.73 & -2.99 & -2.63 \\
\hline & $1^{10}$ Difference: D(ACT) & -6.91 & -2.66 & -1.95 & -1.60 \\
\hline & Level: $F W$ & -0.02 & -4.53 & -3.67 & -3.27 \\
\hline & $1^{\text {II }}$ Difference; $\mathrm{D}(\mathrm{FW})$ & 130 & -2.69 & -1.96 & -1.60 \\
\hline & Level: IC & -0.15 & -4.44 & -3.63 & -3.25 \\
\hline & $1^{2}$ Difference: $D(L C)$ & .0 .77 & -2.69 & -1.95 & -1.60 \\
\hline & $2^{\text {nd }}$ Difference: D(DLC) & -6.77 & -2.69 & -1.95 & -1.60 \\
\hline & Level: MM & -1.98 & -3.73 & -2.99 & -2.63 \\
\hline & 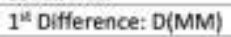 & -6.51 & -2.66 & -1.95 & -1.60 \\
\hline
\end{tabular}




\begin{tabular}{|c|c|}
\hline $\begin{array}{l}\text { Autocorrelation (Breusch-Godfrey Serial } \\
\text { Correlation LM Test) }\end{array}$ & $\begin{array}{l}\text { The } p \text {-value of } f \text {-stat }(0.711) \text { is greater than } 0.05 \text { level of } \\
\text { significance. }\end{array}$ \\
\hline Normality Of Residuals (Jarque-Bera) & $\begin{array}{l}\text { The } p \text {-value of } f \text {-stat }(0.056) \text { is greater than } 0.05 \text { level of } \\
\text { significance. }\end{array}$ \\
\hline Specification Error (Ramsey's RESET) & $\begin{array}{l}\text { The } p \text {-value of } f \text {-stat }(0.702) \text { is greater than } 0.05 \text { level of } \\
\text { significance. }\end{array}$ \\
\hline Multicollinearity (Variance Inflation Factors) & $\begin{array}{l}\text { All } 3 \text { independent variables are less than } 10 \mathrm{VIF}: \\
\bullet(A C T=1.003),(F W=1.574),(L C=1.572)\end{array}$ \\
\hline $\begin{array}{l}\text { Heteroskedasticity } \\
\begin{array}{l}\text { 1. Breusch-Pagan-Godfrey } \\
\text { 2. White }\end{array}\end{array}$ & $\begin{array}{l}\text { 1. The } p \text {-value of } f \text {-stat }(0.623) \text { is greater than } 0.05 \text { level } \\
\text { of significance. } \\
\text { 2. The } p \text {-value of } f \text {-stat }(0.301) \text { is greater than } 0.05 \text { level } \\
\text { of significance. }\end{array}$ \\
\hline Stability (Chow Breakpoint) & $\begin{array}{l}\text { The } p \text {-value of } f \text {-stat }(0.507) \text { is greater than } 0.05 \text { level of } \\
\text { significance. }\end{array}$ \\
\hline
\end{tabular}

(All diagnostic tests are significant; therefore, there are no issues present in the regression model)

\section{Test for Unit Root}

The results show that the variables Agricultural Commodities Transported, Farmers' Wages, and Marketing Margin are stationary at first difference. However, the variable LC is stationary at the second difference. Therefore, the model was regressed at the level.

\section{Test for Autocorrelation}

Autocorrelation or Durbin Watson is used to identify whether there is a similarity between the variables. The result for the autocorrelation test indicates that the $\mathrm{p}$-value of $\mathrm{f}$-stat is greater than 0.05 level of significance which means there is no autocorrelation.

\section{Test for Normality of Residuals}

The Jarque - Bera (JB) Test of Normality is deliberate as a large-sample test that depends on the Ordinary Least Squares (OLS) residuals. Based on the result, the $p$-value of $f$-stat is greater than the 0.05 level of significance; therefore, accept the null hypothesis, which concludes the residuals are normally distributed.

\section{Test for Specification Error}

Ramsey's RESET is used to test different specification errors such as incorrect functional form, redundant and omitted variables. Based on the results, the $p$-value of $f$-stat is greater than the 0.05 level of significance. Misspecification error will be ruled out; therefore, the null hypothesis is accepted.

\section{Test for Multicollinearity}

The Multicollinearity test was applied to identify if two or more independent variables have an existing linear relationship. Based on the result, each independent variable's Variance Inflation Factors (VIF) is significantly less than 10; therefore, accept the null hypothesis that the independent variables are free from serious multicollinearity issues. 


\section{Test for Heteroskedasticity}

The Breusch-Pagan-Godfrey and White Heteroskedasticity Tests were applied to identify if the estimated variance from the regression is dependent on the values of the independent variables and if the regression residuals have unequal variances. Based on the result, the $\mathrm{p}$-value of the $\mathrm{f}$-stat on both tests is greater than 0.05 level of significance; therefore, accept the null hypothesis that the presence of heteroskedasticity is inexistent.

\section{Test for Stability}

The Chow Breakpoint Test was applied to identify the stability of the regression model throughout the years. Based on the result, the $p$-value of the $f$-stat is greater than 0.05 level of significance; therefore, accept the null hypothesis, which determines there is no structural breakpoint.

\subsection{Hypothesis Testing and Results of the Objective \\ - Hypothesis Testing \\ Hypothesis 1:}

Ho: Agriculture Commodities Transported have no significant impact on the Marketing Margin. Ha: Agriculture Commodities Transported have a significant impact on the Marketing Margin.

Conclusion: Accept Null Hypothesis

Hypothesis 2:

Ho: Farmers' Wages have no significant impact on the Marketing Margin.

Ha: Farmers' Wages have a significant impact on the Marketing Margin.

Conclusion: Accept Alternative Hypothesis

Hypothesis 3:

Ho: Logistics Cost has no significant impact on the Marketing Margin.

Ha: Logistics Cost has a significant impact on the Marketing Margin.

Conclusion: Accept Alternative Hypothesis

- $\quad$ Results of the Objective

As mentioned in Chapter 1, the objective of this study was to identify how exogenous variables affect marketing margin. Based on the regression result, the researchers concluded that:

1. Agricultural Commodities Transported and Marketing Margin has a negative relationship. However, it is statistically insignificant on the Marketing Margin.

2. Farmers' Wages and Marketing Margin have a positive relationship.

3. Logistics Cost and Marketing Margin have a negative relationship.

\section{Conclusion}

The paper focused on determining the impact of Logistics Cost on Marketing Margin in the Philippine Agricultural Sector. With the existence of logistics cost in the agricultural process, the middlemen are affected since these intermediaries are the one who transacts with the end customer. Nonetheless, farmers tend to sell their products to middlemen and still profit from them. Specifically, the objectives of this paper were geared towards identifying the relationship of exogenous variables, namely Farmers' Wages (FW) and Logistics Cost (LC), to the Marketing Margin (MM). Based on the statistical results of this research, the researchers concluded that logistics cost has a negative correlation with the marketing margin. Conversely, farmers' wages have a positive relationship to the dependent variable. The researchers have drawn inferences from the 25 observations (annually time-series data), and secondary data was gathered from the Philippine Statistics Authority (PSA). To achieve the aim and objectives of this study, a descriptive-quantitative approach was applied. The impact of FW and LC on the MM was estimated through multiple regression, and all diagnostic tests applied are statistically significant; therefore, there are no issues present in the regression model. This paper accepts the null hypothesis of $\mathrm{H} 1$ and the alternative hypothesis of $\mathrm{H} 2$ and $\mathrm{H} 3$. 


\subsection{Agricultural Commodities Transported to Marketing Margin}

Based on the results of the Ordinary Least Squares (OLS) regression, the relationship of Agricultural Commodities Transported (ACT) to the Marketing Margin (MM) is indirect. Agricultural commodity prices have been unstable throughout time. Nwaigwe et al. (2019) concluded that even with a growing marketing margin, a commodity can still remain inefficient in production. According to Edeme et al. (2020), transportation infrastructure has a negative and insignificant effect on agricultural production. The several authors mentioned in Abassian et al. (2010) study concluded that with the assumption of variable input proportions, a negative relationship between the number of outputs and marketing margin is exhibited.

Logistics is an important factor in the production supply of agricultural commodities. The agricultural process entails transportation and storage activities which are necessary for the middlemen to participate in. However, these are some reasons why ACT is insignificant to the MM: The lack of postharvest facilities causes farmers to incur big losses, and it lessens their capacity to bargain for a higher price since they must sell their produce immediately after harvest. It often results in an oversupply and spoiling, which causes a loss for the farmers. Despite the farmers selling their produce at a lower price, middlemen are still likely to refuse the goods since perishable commodities such as fruits, vegetables, livestock, and meat have a limited shelf life after harvest or production. Thus, farmers do not have market power. Michail and Melas (2021) suggested that due to the distinctive characteristics of agricultural commodities such as perishability and seasonality, its effect on transportation costs can be arbitrary. The study of Yuzhou (2020) also asserts that due to the volatile influences of climate, immediacy and perishability of commodities establish difficulty in stabilizing the demand and supply of such commodities. In this regard, the agricultural commodities transported exhibited an insignificant relationship to the marketing margin.

\subsection{Farmers' Wages to Marketing Margin}

It is a fact that farmers are essential in producing agricultural products in the Philippines and their produced outputs undergo different processes that affect the wages that farmers collect and the marketing margin. Based on the result of the OLS regression, it was shown that Farmers' Wages (FW) and the Marketing Margin (MM) have a direct relationship. These several authors mentioned in Chapter 2 further support the concluded direct correlation of Farmers' Wages to the Marketing Margin. Yuzhou (2020) stated that an increase in agricultural prices also raises the wage of farm employees as a whole. Aguinaldo et al. (2016) emphasized that despite increasing farm and retail price spread or marketing margin per se, farmers are still able to collect higher wages and profit. Moreover, even with the added costs in transacting with middlemen, access to market information increases the amount that farmers receive (Mitchell, 2011). Traub and Jayne (2008) concluded that due to rising marketing costs, prices to farmers decrease. Whereas higher marketing margins likewise increase the farmers' wage rates. Labour-intensive industries such as agriculture have higher prices as wages increase (Delgado, 1992, as cited by Traub \& Jayne, 2008). According to the study of Carambas (2005), the author affirmed that under the presumption of variable input proportion, the relationship of marketing margin to marketing input prices such as wages is positive. Fisher (1981) stated that positive growth in the wage rate can cause an upward shift to the supply curve of marketing inputs, thereby increasing the marketing margin.

Farmers, middlemen, and logistics are all interdependent with each other. Farmers are using the services of the middlemen since these intermediaries can handle market information and transportation in a much efficient manner. Farmers experience asymmetric information, which affects how they transact their produced goods. Middlemen are at an advantage as they are better informed of the prices and demands and hold much larger market power. Moreover, high logistics costs also cause farmers to rely on another mediator to assist in transporting their output as they cannot bear the added costs. Due to this reason, farmers perceive transacting with middlemen on their behalf as a convenient and efficient method. It is mutually beneficial for both parties, especially for smallscale farmers, as they can easily sell their agricultural goods to a middleman. Simultaneously, this intermediary is also fully capable of delivering the goods to another seller in a much larger market. These assertions induce the significant relationship between farmers and middlemen, which manifests through the variables farmers' wages and the marketing margin.

\subsection{Logistics Cost to Marketing Margin}

In the study of Catalbas (2012), they stated that the economics of logistics structure was established because economics and logistics are interrelated. The results of the OLS regression show that Logistics Cost (LC) and Marketing Margin (MM) have an indirect relationship. Transportation costs can be reduced if there's a small distance between producers and consumers. Marketing costs increase when the distance between producers and consumers is far because more intermediaries are involved (Sadah et al., 2021). Mérel et al. (2005) stated that reducing transportation costs and increasing production causes higher farm-level prices. Low transportation costs increase farm prices.

Logistics is essential in the agricultural process and accounts for a significant portion of the marketing margin. In which transportation and storage costs cause agricultural commodities to be more expensive. It usually increases when the distance between producers and consumers is far because more intermediaries are involved. In addition, middlemen play a significant role and are the ones affected by the changes in the logistics cost because although middlemen have more market power than farmers, 
they are still forced to lower the price to sell the commodities at a competitive price. In which, it indicates a significant relationship between Logistics Cost and Marketing Margin.

\subsection{Policy Implication}

Transacting with middlemen appears to be the wisest choice for the farmers as these mediators are better informed of the situation of the market. Due to these reasons, the researchers can address that the presence of a longer supply chain (which results to food wastage, double handling, etc.) asymmetric information, technology, storage and facilities, and added logistics costs in the transaction affect the middlemen and how farmers decide to sell their agricultural outputs and the wage or profit they receive. The policy implication of this paper suggests that comprehensive market information, providing cooperative farming schemes, enhancing marketing infrastructure and financial assistance are key factors for improving the state of the farmers in terms of their productivity, profitability, and efficiency as main producers of agricultural products, which may also open better economic opportunities and position them at a competitive advantage.

These are the existing government policies, projects, and programs that our study can support: (1) The Philippine Rural Development Project is a six-year project that aims to modernize, climate-smart, and market-oriented agri-fishery industry. The project helps with infrastructure, facilities, technology, and information development that will be beneficial to rural development in terms of income, productivity, and competitiveness. This study recommends that some of the projects that can help with the efficiency include Farm-to-Market Road and distribution of farm equipment. Infrastructure development strives to increase the links between production areas and markets to improve the efficiency of transporting agricultural commodities. (2) A direct marketing scheme program called the KADIWA ni Ani at Kita links producers with the consuming public, allowing food commodities at reasonable prices to consumers through accessible Kadiwa retail stores. The financial assistance increases the farmers' wages, thereby increasing the marketing margin.

The financial grant can improve the state of farmers since they can simply sell their products and may need the services of middlemen. Asymmetric information can be omitted since there is direct communication between the farmers and end consumers. The study also suggests that a long supply chain hinders the productivity of both parties, hence ensuring to maintain the essence of the program is necessary to reduce inefficiencies. (3) One Town One Product (OTOP) Philippines is a priority stimulus program for Micro, Small and Medium-scale enterprises (MSMEs) as government's customized intervention to drive inclusive local economic growth. Farmers may also participate in this program to sell their commodities. Once farmers' earnings increase with the help of this program, it can positively affect the profit of middlemen as well. This can further help the program reach its aim of capacitating these producers and gain a competitive advantage. This study also recommends that farmers be involved in cooperatives so it will be easier for them to be recognized as a player and fully realize the programs' benefits.

(4) Agriculture and Fisheries Modernization Act of 1997 aims to modernize Philippine agriculture for the country to compete in the global market. The underlying principle behind this policy is to improve the living conditions of farmers and fisherfolk and increase their productivity amidst the growing needs of the markets. Although logistics inversely affect the marketing margin, it is still necessary to increase farmers' wages, resulting in increased productivity, thereby improving their living conditions. As this study proved, a rise in the farmers' wages can increase the impact or profit of middlemen. Middlemen can support and provide the assistance needed by farmers to duly fulfill their roles as primary producers of agricultural products. Through these findings, it can help the country achieve modernization and at the same time, alleviate the farmers' way of life.

(5) TienDA Malasakit is strategically located around major cities to provide consumers with fresh and affordable agricultural commodities at farm gate prices. The government proposes to make agriculture and fisheries inputs such as equipment, fertilizers, seeds, irrigation, and low-interest credit facilities readily available to farmers and fisherfolk to improve their production. The government plans to provide professional support to farmers and fishermen, such as business and skill training. This program can help the farmers improve their incomes since the government will provide the storage and facilities to sell their products directly to the consumers at competitive prices, frequently using intermediaries' services. Farmers will also be knowledgeable about sustainable farming practices by converting traditional subsistence agriculture into agribusiness via innovation in using equipment and establishing itself as a competent and strong force for advancing the transition to sustainable livelihoods.

(6) Linking Smallholder Farmers to Markets and Microfinance (LinkSFarMM) is an innovative Department of Agrarian Reform that uses a value chain mechanism to help smallholder farmers boost agricultural output and manage their agricultural production properly. This program will assist in improving the lives and productivity of agrarian reform beneficiaries, smallholder farmers, and farmer groups. Farmers could face an oversupply of agricultural commodity produce due to a shortage of market outlets even the establishment of a "pasalubong center" as a different venue for the sale of their goods was unable to resolve their excess issue.

(7) Deliver-E developed in collaboration with the Department of Agriculture and the Department of Trade and Industry, is a comprehensive end-to-end e-commerce platform for agricultural and food commodities and a modernized marketing method 
that connects food producers to consumers without additional trade levels. Uses advanced blockchain technology built by a Filipino IT firm, Insight Supply Chain Solutions (InsightSCS), to combine associated e-commerce and logistics application services from consolidation point to central warehouse facility. Deliver-E will help MSMEs, farmers, and farmers' cooperatives in selling their goods directly to customers. The elimination of middlemen allows items to be offered at low prices while still being fresh. Additionally, the project aims to develop efficient agricultural product transportation and logistics systems, ensure that MSMEs can supply affordable and high-quality agricultural products, and develop a dashboard that will enable the government to collect and analyze real-time data to aid in policy making.

(8) Shared Service Facilities (SSF) aims to improve MSME competitiveness by sharing machines, equipment, tools, systems, accessories, skills, and information. With more markets, sales, and employment, the facilities should assist target recipients to expand their production capacity and quality. There are factors of constraints including limited financial capacity, inadequate market information, and a lack of access to innovative techniques and advanced technology which all make it more difficult for them to realize their full potential, penetrate larger domestic or international markets, and grow in a highly competitive environment. The program of Department of Trade and Industry could designate Shared Service Facilities (SSF) as a flagship initiative to enhance MSME production and efficiency via increased access to technology.

Funding: This research received no external funding.

Acknowledgements: Firstly, we express our gratitude to the Almighty Father for giving us the strength and hope to complete this thesis. We would like to extend our thanks to all of our friends, family, and professors for their unwavering foundation and encouragement over the years. We would like to express our gratitude to the Business Economics Department of the University of Santo Tomas for providing us with this opportunity. Lastly, we would like to offer our heartfelt gratitude to Mr. Peter Jeff C. Camaro, M.A., our research advisor, for his guidance, patience, and support during our research journey. He has been a tremendous help to us.

Conflicts of Interest: The authors declare no conflict of interest.

\section{References}

[1] Abassian, M., Shirani-Bidabadi, F., \& Ebrahimzadeh, H. (2010). Efficiency of date marketing system in Sistan \& Bluchestan of Iran; a marketing margin approach. Agricultural Economics (Zemědělská Ekonomika), 56(1), 43-50. https://www.agriculturejournals.cz/publicFiles/7 2009-AGRICECON.pdf

[2] Abebe, G. K., Bijman, J., \& Royer, A. (2015). Are middlemen facilitators or barriers to improving smallholders' welfare in rural economies? Empirical evidence from Ethiopia. Journal of Rural Studies, 43, 203-213. https://doi.org/10.1016/j.jrurstud.2015.12.004

[3] Adamopoulos, T. (2011). Transportation Costs, Agricultural Productivity, and Cross-Country Income Differences. International Economic Review, 52(2), 489-521. https://doi.org/10.1111/j.1468-2354.2011.00636.x

[4] Afolabi, O. J., Oluwaji, O. A., \& Onifade, T. A. (2018). Transportation Factors in the Distribution of Agricultural Produce to Urban Center in Nigeria. LOGI - Scientific Journal on Transport and Logistics, 9(1), 1-10. https://doi.org/10.2478/logi-2018-0001

[5] Aguinaldo, R.T., Sarmiento, J.M.P., Digal, L.N., Balgos, C.Q. \& Hall, D. (2016). Analyzing price spreads and net margins of smallholder vegetable farmers in the southern Philippines. Acta Hortic. 1128, 271-276. https://doi.org/10.17660/ActaHortic.2016.1128.41

[6] Ajiboye, A.O, \& Afolayan, O. (2009). The impact of transportation on agricultural production in a developing country: a case study of kolanut production in Nigeria. International Journal of Agricultural Economics and Rural Development, 2(2) 49-57. https://www.semanticscholar.org/paper/The-impact-of-transportation-on-agricultural-in-a-\%3A-AjiboyeAfolayan/6087c271a18b9e11b6cce5ca7c7deb4f516f44f0

[7] Bayramoğlu, A. T. (2014). The Impact of Agricultural Commodity Price Increases on Agricultural Employment in Turkey. Procedia - Social and Behavioral Sciences, 143, 1058-1063. https://doi.org/10.1016/j.sbspro.2014.07.555

[8] Binswanger, H.P., \& Singh, S.K. (2017). Wages, Prices and Agriculture: How Can Indian Agriculture Cope with Rising Wages? Journal of Agricultural Economics, 69(2), 281-305. https://doi.org/10.1111/1477-9552.12234

[9] Bokor, Z. \& Markovits-Somogyi, R. (2011) Efficiency in transport logistics. In: Logistics Yearbook 2011, Magyar Logisztikai Egyesület. Keszthely. p. $19-27$.

[10] Brorsen, B. W., Chavas, J., Grant, W. R., \& Schnake, L. D. (1985). Marketing Margins and Price Uncertainty: The Case of the U.S. Wheat Market. American Journal of Agricultural Economics, 67(3), 521-528. https://doi.org/10.2307/1241071

[11] Calicdan, J. P. J., Gavino, C. J., Estrada, H. F., Cortez, J. M., \& Balaria, F. E. (2020). Effects of Rice Liberalization Law on Rice Production, Farmers' Wages and Government Budgets. International Journal of Advanced Engineering, Management and Science, 6(6), p. $275-281$. https://dx.doi.org/10.22161/ijaems.66.7

[12] Camisón-Haba, S., \& Clemente-Almendros, J. A. (2019). A global model for the estimation of transport costs. Economic Research-Ekonomska Istraživanja, 33(1), 2075-2100. https://doi.org/10.1080/1331677X.2019.1584044

[13] Carambas, M.C, (2005). Analysis of Marketing Margins in Eco-Labeled Products. Center for Development Research, University of Bonn. 1-16. http://dx.doi.org/10.22004/ag.econ.24600 
[14] Catalbas, N., (2012). Lojistik ilkeleri [Logistics principles]. Anadolu Universitesi Acikogretim Yayinları [Anadolu University Open Education Publications]. Yayın No: 2517.

[15] Ceniga, P., \& Sukalova, V. (2015). Future of Logistics Management in the Process of Globalization. Procedia Economics and Finance, 26, 160166. https://doi.org/10.1016/S2212-5671(15)00908-9

[16] Clements III, J.S. (2010). Agricultural Commodity Futures and Farmland Investment: A Regional Analysis. Dissertation. Georgia State University. p. 1-107. https://scholarworks.gsu.edu/real estate diss/8

[17] Dawe, D., \& Maltsoglou, I. (2014). Marketing margins and the welfare analysis of food price shocks. Food Policy, 46, 50-55. http://dx.doi.org/10.1016/j.foodpol.2013.12.010

[18] Dawe, D. C., Moya, P. F., Casiwan, C. B., \& Cabling, J. M. (2008). Rice marketing systems in the Philippines and Thailand: Do large numbers of competitive traders ensure good performance? Food Policy, 33(5), 455-463. http://dx.doi.org/10.1016\%2Fj.foodpol.2008.02.001

[19] Digal L., Elcana E., Concepcion S., Hualda L., \& Rasco E. (2006). Marketing margin analysis: quality premiums and inefficiencies in the Southern Philippine vegetable industry. Stewart Postharvest Review 2(3): 1-7. http://dx.doi.org/10.2212/spr.2006.3.7

[20] Ebarle, E. (2013). A Comparative Analysis Of Marketing Margins Of Fruit And Vegetables In Mindanao, The Philippines. Acta Horticulturae, 1006, 143-147. https://doi.org/10.17660/ActaHortic.2013.1006.16

[21] Edeme, R. K., Nkalu, N. C., Idenyi, J. C., \& Arazu, W. O. (2020). Infrastructural Development, Sustainable Agricultural Output and Employment in ECOWAS Countries. Sustainable Futures, 2, 100010. https://doi.org/10.1016/j.sftr.2020.100010

[22] Fang-asan, M.D., Dagupen, M. T. \& Digal, L. N. (2009). "Lettuce Supply Chains and Marketing Margins in Benguet, Philippines," BANWA: A Multidisciplinary Journal, University of the Philippines Mindanao, 6(2), 1-11. http://dx.doi.org/10.22004/ag.econ.145552

[23] Ferro, E., Otsuki, T., \& Wilson, J. (2015). The effect of product standards on agricultural exports. Food Policy, 50. http://dx.doi.org/10.1016/j.foodpol.2014.10.016

[24] Fisher, B.S. (1981). The impact of changing marketing margins on farm prices. American Journal of Agricultural Economics 63, $261-263$. https://doi.org/10.2307/1239562

[25] Gardner, B.L. (1975). The Farm-Retail Price Spread in a Competitive Food Industry. American Journal of Agricultural Economics 57(3), 399409. https://doi.org/10.2307/1238402

[26] Gebresenbet, G., \& Bosona, T. (2012). Logistics and Supply Chains in Agriculture and Food. Pathways to Supply Chain Excellence, $125-146$. https://doi.org/10.5772/25907

[27] Gollin, D., \& Rogerson, R. (2014). Productivity, transport costs and subsistence agriculture. Journal of Development Economics, $107,38-48$. https://doi.org/10.1016/j.jdeveco.2013.10.007

[28] Gonzaga, R. N., Hwang, H. S., \& Shin, D. H. (2020). A Comparative Study of Agricultural Products Wholesale Markets in the Philippines and South Korea for Future Development Planning. Journal of International Development Cooperation, 15(2), 113-139. https://doi.org/10.34225/jidc.2020.15.2.113

[29] Granillo-Macías, R., Olivares-Benítez, E., Martínez-Flores, J.L., \& Cabarello-Morales, S.O. (2018) Analysis Of Logistic Cost In Contract Agriculture: The Case Of Barley Supply Chain In Hidalgo, México. Brazilian Institute of Information in Science and Technology, 14(1), 164-183. https://www.cabdirect.org/cabdirect/abstract/20183207410

[30] Gu, Y., \& Dong, S. (2016). Logistics Cost Management from the Supply Chain Perspective. Journal of Service Science and Management, 09(03), 229-232. http://dx.doi.org/10.4236/jssm.2016.93028

[31] Gujarati, D. (2004). Basic Econometrics 4th Edition. New York: McGraw-Hill.

[32] Hadi, P. U. (1990). Analysis of Marketing Margin Behaviour Using Econometric Model: The Case of Groundnut in East Java. Indonesian Agency for Agricultural Research and Development Ministry of Agriculture, 26-40. http://dx.doi.org/10.21082/jae.v9n1.1990.26-40

[33] Han, J. (2017). Construction and optimization of logistics supply chain model based on Fresh agricultural products. Advances in Social Science, Education and Humanities Research, 101, 858-862. https://dx.doi.org/10.2991/icemct-17.2017.184

[34] Heien, D. M. (1977). Price Determination Process for Agricultural Sector Models. American Journal of Agricultural Economics 59, $126-132$. https://doi.org/10.2307/1239616

[35] Jassam, Q.T., Ali, N. \& Shukur, A.S. (2018). Economic study to measure the efficiency and marketing margins of the main vegetable crops Baghdad Province for the Agricultural Season 2016. IOSR Journal of Agriculture and Veterinary Science 11(7). https://www.iosrjournals.org/iosr-javs/papers/Vol11-issue7/Version-1/B1107011115.pdf

[36] Jhawar, A., Garg, S. K., \& Khera, S. N. (2017). Improving logistics performance through investments and policy intervention: a causal loop model. International Journal of Productivity and Quality Management, 20(3), 363. http://dx.doi.org/10.1504/IJPQM.2017.10003289

[37] Johansen, S. (1988). Statistical analysis of cointegration vectors. Journal of Economic Dynamics and Control, 12(2-3), 231-254. https://doi.org/10.1016/0165-1889(88)90041-3

[38] Lean, H.H., Huang, W., \& Hong, J. (2014). Logistics and economic development: Experience from China. Transport Policy, $32,96-104$. https://doi.org/10.1016/j.tranpol.2014.01.003

[39] Liapis, P. \& Tsigas, M. (2014). Trade-In Value-Added of Agricultural and Food Products. Mimeo.

[40] Liu, C., Zheng, H., Sheng, K., Liu, W., \& Zheng, L. (2018). Effects of melatonin treatment on the postharvest quality of strawberry fruit. Postharvest Biology and Technology, 139, 47-55. https://doi.org/10.1016/j.postharvbio.2018.01.016

[41] Llanto, G. M., Quimba, F. A. \& Sombilla, M. A., (2012). "Interregional Trade of High-value Fruits and vegetables: Issues on Transport and Shipping," Discussion Papers DP 2012-08, Philippine Institute for Development Studies. https://dirp4.pids.gov.ph/ris/dps/pidsdps1208.pdf

[42] Mahan, M.Y., Chorn, C.R., \& Georgopoulos, A. (2015). White Noise Test: detecting autocorrelation and nonstationarities in long time series after ARIMA modelling. In: Proceedings 14th Python in Science Conference. http://dx.doi.org/10.25080/Majora-7b98e3ed-00f 
[43] Mandizvidza, K. (2017). Analyzing Marketing Margins and the Direction of Price Flow in the Tomato Value Chain of Limpopo Province, South Africa. International Journal of Environmental \& Agriculture Research (IJOEAR), 3(3), 72-82. https://ijoear.com/Paper-March-2017/IJOEARMAR-2017-13.pdf

[44] Mérel, P. R., Sexton, R. J., \& Suzuki, A. (2006). Transportation cost and market power of middlemen: A spatial analysis of agricultural commodity markets in developing countries. SSRN Electronic Journal. https://dx.doi.org/10.2139/ssrn.944167

[45] Michail, N. A., \& Melas, K. D. (2021). Market interactions between agricultural commodities and the dry bulk shipping market. The Asian Journal of Shipping and Logistics, 37(1) 73-81. http://dx.doi.org/10.1016/j.ajsl.2020.07.003

[46] Mitchell, T. (2011) Middlemen, Bargaining and Price Information: Is Knowledge Power? Mimeo, London School of Economics. https://www.semanticscholar.org/paper/Middlemen-\%2C-Bargaining-and-Price-Information-\%3A-Is-\%E2\%88\%97Mitchell/16a8a95e7e8a5fcbbd3dc7526dadd62b237d8f29

[47] Mitra, S., Mookherjee, D., Torero, M., \& Visaria, S. (2018). Asymmetric Information and Middleman Margins: An Experiment with Indian Potato Farmers. The Review of Economics and Statistics, 100(1), 1-13. https://doi.org/10.1162/REST a 00699

[48] Mopera, L.E. (2016). Food Loss in the Food Value Chain: The Philippine Agriculture Scenario. Journal of Developments in Sustainable Agriculture, 11, 8-16. https://doi.org/10.11178/jdsa.11.8

[49] Naidu, S., Pandaram, A., \& Chand, A. (2017). A Johansen Cointegration Test for the Relationship between Remittances and Japan's Economic Growth. Modern Applied Science, 11(10), 137. https://doi.org/10.5539/mas.v11n10p137

[50] Negi, D. S., Birthal, P. S., Roy, D., \& Khan, M. T. (2018). Farmers' choice of market channels and producer prices in India: Role of transportation and communication networks. Food Policy, 81, 106-121. https://doi.org/10.1016/j.foodpol.2018.10.008

[51] Nuthalapati, C. S., Sutradhar, R., Reardon, T., \& Qaim, M. (2020). Supermarket procurement and farmgate prices in India. World Development, 134, 105034. https://doi.org/10.1016/j.worlddev.2020.105034

[52] Nwaigwe, G. C., Lemchi, J. I., \& Korie, O. C., (2019). Analysis Of Marketing Margin And Efficiency Of Beans In Imo State. International Journal of Scientific \& Engineering Research, 10(12), 212-223.https://www.ijser.org/researchpaper/ANALYSIS-OF-MARKETING-MARGIN-ANDEFFICIENCY-OF-BEANS-IN-IMO-STATE.pdf

[53] Oguoma, O., Nkwocha, V., \& Ibeawuchi, I. (2010). Implications of middlemen in the supply chain of agricultural products. Journal Of Agriculture And Social Research (JASR), 10(2). https://doi.org/10.4314/jasr.v10i2.67575

[54] Park, H. G., \& Lee, Y. J. (2015). The Efficiency and Productivity Analysis of Large Logistics Providers Services in Korea. The Asian Journal of Shipping and Logistics, 31(4), 469-476. https://doi.org/10.1016/j.ajsl.2016.01.005

[55] Parung J., Santoso A., Prayogo D. N., Angelina M., Tayibnapis A. Z., \& Djoemadi F. R. (2015). Designing Efficient Logistic System of Fresh Agricultural Products for Small Farms. Journal of Electrical and Electronic Engineering, 3(5), 146-149. http://dx.doi.org/10.11648/j.jeee.20150305.18

[56] Perdana, Y. R. (2012). Logistics Information System for Supply Chain of Agricultural Commodity. Procedia - Social and Behavioral Sciences, 65, 608-613. http://dx.doi.org/10.1016/j.sbspro.2012.11.172

[57] Philippine Statistics Authority. (2018). 2018 Philippine Statistical Yearbook. https://psa.gov.ph/products-andservices/publications/philippine-statistical-yearbook

[58] Piabuo, S. M., Yakan, H. B., Puatwoe, J. T., Nonzienwo, V. Y., \& Mamboh, T. R. (2020). Effect of rural farmers' access to information on price and profits in Cameroon. Cogent Food \& Agriculture, 6(1), 1799530. https://doi.org/10.1080/23311932.2020.1799530

[59] Pokhrel, D. M., \& Thapa, G. B. (2007). Are marketing intermediaries exploiting mountain farmers in Nepal? A study based on market price, marketing margin and income distribution analyses. Agricultural Systems, 94(2), 151-164. https://doi.org/10.1016/j.agsy.2006.08.004

[60] Randall, W. S., \& Theodore Farris, M. (2009). Supply chain financing: using cash-to-cash variables to strengthen the supply chain. International Journal of Physical Distribution \& Logistics Management, 39(8), 669-689. http://dx.doi.org/10.1108/09600030910996314

[61] Rivera-Padilla, A. (2020). Crop choice, trade costs, and agricultural productivity. Journal of Development Economics, $146,102517$. https://doi.org/10.1016/j.jdeveco.2020.102517

[62] Russo, C., \& Goodhue, R. (2017). Farmgate prices, retail prices, and supermarkets' pricing decisions: An integrated approach. Agribusiness, 34(1), 24-43. https://doi.org/10.1002/agr.21530

[63] Saadah, Salam, M., Asmawati, \& Sakia, N. (2021). Measuring margin and efficiency of the Rice Marketing Channel. IOP Conference Series: Earth and Environmental Science, 681(1), 012107. https://doi.org/10.1088/1755-1315/681/1/012107

[64] Sandika, A. (2012). Impact of Middlemen on Vegetable Marketing Channels in Sri Lanka. Tropical Agricultural Research and Extension, 14(3), 58. http://doi.org/10.4038/tare.v14i3.4843

[65] Sezer, S. \& Abasiz, T., (2017). The Impact Of Logistics Industry On Economic Growth: An Application In OECD Countries. Eurasian Journal of Social Sciences, 5(1), 11-23. http://dx.doi.org/10.15604/ejss.2017.05.01.002

[66] Shang, P., Xue, J., \& Xu, Y. (2014). The Analysis based on the Logistics Cost Controlling of the Fresh Agricultural Products. Atlantis Press, 1197-1201. https://www.atlantis-press.com/proceedings/lemcs-14/13171

[67] Silva, T. F., Gonçalves, A. T., \& Leite, M. S. (2014). Logistics cost management: insights on tools and operations. International Journal of Logistics Systems and Management, 19(3), 329. https://www.researchgate.net/profile/Anderson-Goncalves9/publication/274719688 Logistics cost management Insights on tools and operations/links/5b0b7bbca6fdcc8c25346056/Logistics-costmanagement-Insights-on-tools-and-operations.pdf

[68] Sotelo, S. (2020). Domestic Trade Frictions and Agriculture. Journal of Political Economy, 128(7), 2690-2738. http://dx.doi.org/10.1086/706859 
[69] Stainer, A. (1997), "Logistics - a productivity and performance perspective", Supply Chain Management: An International Journal, 2(2) 53 62. https://doi.org/10.1108/13598549710166104

[70] Tomek, W.G., \& K.L. Robinson (1981), "Marketing margins for farm products", in Agricultural Product Prices, 2nd edn. (Cornell Univ. Press, Ithaca, N.Y.) Chapter 6.

[71] Traub, L. N., \& Jayne, T. (2008). The effects of price deregulation on maize marketing margins in South Africa. Food Policy, 33(3), 224-236. http://dx.doi.org/10.1016/j.foodpol.2007.10.004

[72] Trinh, T.H. (2014) A New Approach to Market Equilibrium. International Journal of Economic Research, 11, 569-587. https://www.researchgate.net/publication/320064646 A New Approach to Market Equilibrium

[73] Tseng, Y., Taylor, M. A. P., \& Yue, W. L. (2005). The Role Of Transportation In Logistics Chain. Proceedings of the Eastern Asia Society for Transportation Studies, 5, 1657-1672. https://archive.siam.org/journals/plagiary/1657.pdf

[74] Tunde, A., \& Adeniyi, E. (2012). Impact of Road Transport on Agricultural Development: A Nigerian Example. Ethiopian Journal of Environmental Studies and Management, 5(3), 232-238. https://doi.org/10.4314/ejesm.v5i3.3

[75] Verma, M. (2010). Assessing The Poverty Impacts When Commodity Prices Are Volatile. Dissertation. Purdue University Libraries and School of Information Studies, 1-143. https://www.researchgate.net/publication/254638677 Assessing the poverty impacts when commodity prices are volatile

[76] Wajszczuk, K., (2016). The role and importance of logistics in Agri-Food Supply Chains: An overview of empirical findings. Logistics and Transport., 2, 47-55. https://www.researchgate.net/publication/305478060 The Role and Importance of Logistics in AgriFood Supply Chains An Overview of Empirical Findings

[77] Wohlgenant, M.K. (2001). Marketing Margins: Empirical Analysis. Handbook of Agricultural Economics, Elsevier Science 1(B) $933-970$. https://doi.org/10.1016/S1574-0072(01)10024-1

[78] Wohlgenant, M.K. \& J.D. Mullen. (1987). Modelling the Farm-Retail Price Spread for Beef. Western Journal of Agricultural Economics 12, 119125. http://dx.doi.org/10.22004/ag.econ.32229

[79] World Bank. (2020). Transforming Philippine Agriculture: During COVID-19 and Beyond. World Bank, Washington, DC. (c) World Bank. http://hdl.handle.net/10986/34012

[80] Yuzhou, L. (2020). A study on agricultural production and cost of logistics operation based on Analytic Hierarchy Process. Brazilian Institute of Information in Science and Technology, 16(2), 322-344. http://www.custoseagronegocioonline.com.br/numero2v16/OK\%2014\%20logistics.pdf

[81] Zant, W. (2018). Trains, Trade, and Transaction Costs: How Does Domestic Trade by Rail Affect Market Prices of Malawi Agricultural Commodities? The World Bank Economic Review, 32(2), 334-356. https://doi.org/10.1093/wber/lhx011 